\title{
COVID-19: REFLEXÕES SOBRE SEUS IMPACTOS NA QUALIDADE DO AR E NAS MODIFICAÇÕES CLIMÁTICAS
}

\author{
José Claudio Junqueira Ribeiro ${ }^{1}$ \\ Escola Superior Dom Helder Câmara (ESDHC) \\ Maraluce Maria Custódio \\ Escola Superior Dom Helder Câmara (ESDHC)
}

Diego Henrique Pereira Praça ${ }^{3}$

Escola Superior Dom Helder Câmara (ESDHC)

\section{RESUMO}

A atmosfera é um dos elementos do meio ambiente natural mais impactados pelo ser humano e que gera reflexos diretos na qualidade de vida do planeta, seja pela piora da qualidade do ar, seja pelas modificações climáticas. Nesse sentido, analisa-se neste artigo a importância do meio atmosférico como elemento essencial à vida e os impactos sobre a qualidade do ar relacionados ao vírus SARS-CoV-2, causador da atual pandemia de COVID-19. O presente estudo busca apresentar as causas e efeitos das modificações climáticas e da poluição do ar, indicando como a pandemia da COVID-19 tem se relacionado com estes problemas ambientais de forma positiva e negativa. $\mathrm{O}$ método adotado foi o hipotético-dedutivo, com abordagem qualitativa de pesquisa baseada em artigos, análises de documentos e sites oficiais de divulgação de dados. Tem por marco teórico a teoria de Taylor (1981), que apresenta a necessidade de criação de princípios morais para a relação dos seres humanos com o meio natural. Conclui, por fim, que é necessária uma rediscussão sobre a relação ser humano e mundo

1 Doutor em Saneamento, Meio Ambiente e Recursos Hídricos pela Universidade Federal de Minas Gerais (UFMG). Diplôme de Études Approfondies (DEA) em Génie Sanitaire et Urbanisme pela École Nationale de Santé Publique (ENSP). Especialista em Engenharia Sanitária e Graduado em Engenharia Civil pela Escola de Engenharia da UFMG. Professor do Programa de Mestrado e Doutorado em Direito Ambiental e Desenvolvimento Sustentável da ESDHC. ORCID: https://orcid. org/0000-0002-6626-4557 / e-mail: jcjunqueira@yahoo.com

2 Doutora em Geografia pela UFMG, em programa de cotutela com a Université d'Avignon. Mestre em Direito pela UFMG e em Direito Ambiental pela Universidad International de Andalucía (UNIA). Graduada em Direito pela UFMG. Professora da graduação e professora permanente do Programa de Pós-Graduação em Direito da ESDHC (Mestrado e Doutorado em Direito Ambiental e Desenvolvimento Sustentável). ORCID: https://orcid.org/0000-0003-2048-7883 / e-mail: maralucemc@gmail.com

3 Mestrando em Direito Ambiental e Desenvolvimento Sustentável pelo Programa de Pós-graduação da ESDHC. Bacharel em Direito pela ESDHC. E-mail: diegopereirapraca@hotmail.com 
natural e repensar os princípios morais e sociais com base nos princípios ambientais, para que se possa evitar futuras epidemias e reduzir os efeitos climáticos.

Palavras-chave: aquecimento global; atmosfera; Taylor; COVID-19; qualidade do ar.

\section{COVID 19: THINKING ABOUT ITS IMPACTS ON AIR QUALITY AND CLIMATE CHANGE}

\section{ABSTRACT}

The atmosphere is one of the elements of the natural environment most impacted by the human being and that generates direct reflections on the quality of life of the planet, either by the air quality, or by the climatic changes. Thus, this article analyzes the importance of the atmospheric environment as an essential element to life and the impacts on the air cause by the SARS-CoV-2, virus that started the current COVID-19 pandemic. The present study presents the causes and effects of climate changes and air pollution, suggesting how the COVID-19 pandemic has been positively and negatively related to these environmental problems. The method adopted is the hypothetical-deductive, with qualitative research approach based on articles, analysis of documents and official data dissemination sites. As the theoretical framework, the Taylor's theory (1981) is embraced as it presents the need to create moral principles for the relationship among human beings and the natural environment. It concludes that it is necessary to re-discuss the relationship among human beings and the natural world, and to rethink social and moral principles based on environmental principles, so that future epidemics can be avoided, and climate effects reduced.

Keywords: air quality; atmosphere; atmospheric pollutants; C Taylor; COVID-19; global warming. 


\section{INTRODUÇÃO}

As políticas públicas que se relacionam com a questão ambiental surgiram, em muitos países, a partir da Convenção de Estocolmo de 1972, mas, no Brasil, elas se iniciam com a Lei 6.938 de 31 de agosto de 1981, denominada Lei da Política Nacional de Meio Ambiente (PNMA), recepcionada pela Constituição da República Federativa do Brasil de 1988 (CRFB/1988), que dedicou um capítulo para o meio ambiente, garantindo a todos os brasileiros o direito a um meio ambiente ecologicamente equilibrado, que, segundo Cirne (2019, p. 223), "traça de maneira moderna e avançada as balizas da proteção ambiental e consagra no texto brasileiro as cinco bases comuns da constitucionalização do meio ambiente".

Nesse sentido, destaca-se neste trabalho a importância do meio atmosférico como elemento essencial à vida e os impactos que o vírus SARS-CoV-2, ou simplesmente novo coronavírus, agente patógeno da pandemia da COVID-19, que provocou mudanças na atmosfera terrestre e na qualidade do ar em todo o mundo - mesmo que de forma temporária - e deu início a uma nova reflexão sobre a relação do ser humano com o mundo natural.

Imagens de satélite mostram que a pandemia do coronavírus está temporariamente diminuindo níveis de poluição do ar ao redor do mundo. Especialistas apontam a quarentena como o evento de maior escala já registrado em termos de redução de emissões industriais. A Agência Espacial Europeia (ESA) detectou ainda uma redução de dióxido de nitrogênio $\left(\mathrm{NO}_{2}\right)$, composto químico que contribui para a poluição atmosférica e para a chuva ácida. $\mathrm{O} \mathrm{NO}_{2}$ é resultado de emissões de carros e outros processos industriais, podendo, entre outras coisas, causar problemas respiratórios (UFJF, 2020).

A atmosfera terrestre, ou simplesmente ar, na composição média que se conhece atualmente, levou bilhões de ano para se estabilizar nessa massa gasosa que envolve o Planeta Terra, composta principalmente por nitrogênio e oxigênio, sendo este último o responsável pelo desenvolvimento de seres aeróbicos ${ }^{4}$, entre os quais se incluem os seres humanos e muitos animais.

A respiração humana e de muitos animais é realizada pela troca gasosa no aparelho respiratório, entre o oxigênio livre do ar e o gás carbônico eliminado pelo metabolismo dos corpos, sendo uma função inerente desses seres e que garante a vida no planeta.

4 Seres que precisam de oxigênio livre no ar ou nas águas para respirar. 
Ao aspirar o oxigênio presente no ar, elemento essencial à vida humana, aspira-se também as impurezas que nele existem, sejam partículas, gases ou outros contaminantes de natureza biológica, como bactérias e vírus.

Hodiernamente, as preocupações com a atmosfera terrestre apresentam duas grandes vertentes: as de origem planetária, como o problema do aquecimento global, e as relativas à poluição do ar local ou regional, que impactam a saúde e o meio ambiente no local e em geral. No primeiro caso, as atividades antrópicas que emitem Gases de Efeito Estufa (GEE) são as principais causas porque potencializam o Efeito Estufa natural da atmosfera terrestre, aumentando a temperatura média do planeta, gerando mudanças climáticas, que podem gerar efeitos catastróficos para muitos tipos de vida na Terra.

A poluição atmosférica, nos níveis local e regional, altera a qualidade do ar, impactando a saúde, a flora, a fauna, o desenvolvimento socioeconômico e o patrimônio, enfim, o meio ambiente de maneira geral. Partículas e gases poluentes aspirados causam danos ao aparelho respiratório e a outros órgãos vitais, apresentando muitas vezes toxicidade e potencial cancerígeno. Muitos gases conferem acidez ao ar, danificando a vegetação, e o patrimônio, situação agravada com a sedimentação de partículas mais pesadas que se depositam sobre as folhas dificultando a respiração dos vegetais e sobre os materiais, acelerando o processo de desgaste, danificando-os, principalmente os bens históricos e culturais ao relento.

Se, até então, as preocupações ambientais vinham se pautando por essas alterações de ordem física, química ou físico-química do ar, a pandemia da COVID-19 trouxe à tona a necessidade de se preocupar com as alterações de ordem biológica, vez que as gotículas expiradas no processo de respiração de pessoas contaminadas, contendo o coronavírus, podem permanecer suspensas no ar por breves momentos, ou se prolongar, em função das condições do ambiente, se fechado ou aberto, umidade, temperatura e correntes de vento.

O presente artigo aborda as causas e efeitos das modificações climáticas e da poluição do ar, indicando como a pandemia da COVID-19 tem se relacionado com estes problemas ambientais de forma positiva e negativa.

O método adotado foi o hipotético-dedutivo com abordagem qualitativa de pesquisa baseada em artigos, análises de documentos e sites oficiais de divulgação de dados. Tem por marco teórico a teoria de Taylor (1981), que defende a necessidade de criação de novos princípios morais pelos seres humanos para se relacionar com o meio natural. Busca, ao 
fim, demonstrar que a pandemia da COVID-19 trouxe aspectos negativos, mas também positivos para a relação ser humano e mundo natural e uma abertura à reflexão sobre a real e prática possibilidade de mudar esta relação criando uma relação de respeito, através de princípios morais baseados nos princípios ambientais, que podem mudar os rumos das modificações climáticas em médio e longo prazo.

\section{ATMOSFERA TERRESTRE: ELEMENTO ESSENCIAL À VIDA E SUAS MODIFICAÇÕES PELAS AÇÕES HUMANAS}

A atmosfera terrestre é a camada de ar que envolve o Planeta Terra, sendo constituída por radiação, gases e material particulado, sua extensão é quilométrica e é primordial para a condição de sobrevivência das espécies. Os processos físicos e químicos que ocorrem minimizam a incidência da radiação ultravioleta e são responsáveis pela manutenção da temperatura média da Terra, permitindo o desenvolvimento e a sobrevivência dos seres vivos. Nesse sentido, lecionam Dias, Andrade-Neto e Miltão (2007, p. 23):

Chama-se atmosfera terrestre a camada composta por radiação, gases e material particulado (aerossóis) que envolve a Terra e se estende por centenas de quilômetros. Os limites inferiores da atmosfera são, obviamente, as superfícies da crosta terrestre e dos oceanos. Contudo, os seus limites superiores não são bem definidos porque, com o aumento da altitude, a atmosfera vai se tornando cada vez mais tênue, em relação ao seu conteúdo de matéria, até que ela se confunda com o meio interplanetário. Para se ter uma ideia de quão rarefeita materialmente a atmosfera se torna à medida que se afasta da superfície terrestre, basta saber que $99 \%$ de sua massa está contida numa camada de $\approx 32 \mathrm{~km}$. Para efeito de comparação lembremos que o raio da Terra é $\approx 6300 \mathrm{~km}$. O conhecimento da composição e comportamento da atmosfera possui uma grande e fundamental relevância para os processos biológicos já que processos físicos e químicos que ocorrem na atmosfera protegem os organismos da exposição à radiação ultravioleta em níveis perigosos, além de que a atmosfera contém os gases e os componentes da radiação necessários para os processos vitais na Terra como, por exemplo, respiração e fotossíntese.

A atmosfera terrestre, denominada didaticamente como Ar, é composta basicamente por Nitrogênio (78\%), Oxigênio (20,8\%), Gás Carbônico $(0,9 \%)$ e o restante $(0,3 \%)$ por outros gases como argônio, criptônio, hélio, neônio, radônio e xenônio, metano, dióxido de enxofre e vapor d'água. (BRANCO, 1982).

Didaticamente, a atmosfera é dividida em camadas que juntas se estendem por mais de mil quilômetros de altitude e à medida que se afastam 
da superfície da Terra se tornam mais rarefeitas. Os limites de cada camada são marcados por inflexões na temperatura. (PERES, 2008).

A camada denominada Troposfera estende-se da superfície da Terra por cerca de 15 a $18 \mathrm{~km}$ de altitude, na linha do Equador, e de cerca de 6 a $8 \mathrm{~km}$, nos polos. Esta camada corresponde a $80 \%$ do peso atmosférico e nela ocorrem o desenvolvimento da vida e os fenômenos meteorológicos. A partir da Troposfera, tem-se a Estratosfera, que se estende até cerca de $50 \mathrm{Km}$ de altitude, onde se situa a camada de Ozônio, responsável pela filtragem dos raios ultravioletas. A terceira camada é a Mesosfera que está situada entre 50 e $90 \mathrm{~km}$ de altitude, seguida da quarta camada denominada Termosfera que se estende até cerca de $450 \mathrm{~km}$ de altitude. A quinta e última camada considerada é a Exosfera, até cerca de $900 \mathrm{~km}$ de altitude, onde o ar é rarefeito e há o escape dos gases para o espaço (PERES, 2008).

$\mathrm{O}$ ar é elemento indispensável à vida em todas as suas formas, pois a respiração dos seres humanos e dos outros seres vivos depende do oxigênio livre $\left(\mathrm{O}_{2}\right)$ no ar, necessário à troca gasosa de absorção do $\mathrm{O}_{2}$ e lançamento de gás carbônico $\mathrm{CO}_{2}$, ou a absorção deste para a produção do oxigênio pelos vegetais. A composição do ar - atmosfera - garante a temperatura, os componentes para a existência da vida, bem como sua movimentação, além da regulação climática, que, em conjunto com vários fatores ao mesmo tempo, pode mudar esses ciclos, tais como os ciclos solares, a deriva dos continentes, o vulcanismo e as interferências antrópicas.

As interferências humanas nos processos naturais atmosféricos - por meio de emissão de gases, partículas e, na biodiversidade, pela mudança de sua estrutura como transformação de vegetação de áreas - pela agricultura - ou de inserção de construções -cidades -, acarretam alterações na composição natural dessa camada de ar, podendo provocar efeitos indesejáveis à saúde e à qualidade de vida dos seres vivos do planeta. Essas interferências podem ser de ordem, física (partículas), químicas (gases) ou biológicas (bactérias e vírus).

As alterações da qualidade do ar, de natureza física, química ou biológica podem causar impactos ambientais de natureza global, regional ou local. Os exemplos mais clássicos de impactos globais são as mudanças climáticas decorrentes do aquecimento global e o buraco na camada de ozônio decorrente da emissão de substâncias que a deterioram como os clorofluorcarbonos. No caso de impactos locais e regionais, citam-se as alterações da qualidade do ar pelas emissões de poluentes por fontes fixas e móveis presentes numa determinada área, como indústrias e veículos 
automotores, bem como as retiradas de vegetação que liberam carbono, antes fixados pelos seus elementos. Demonstrando que a forma que hoje os seres humanos se relacionam com a natureza não tem sido harmoniosa, fazendo-se necessária a mudança de perspectiva da relação, que exige, assim, novos preceitos éticos.

Nessas searas, alterações de ordem biológica do ar, per se, nunca tiveram destaque, mas com a pandemia da COVID-19, as atenções se voltam para a necessidade de aprofundar conhecimentos, pois, ao analisar as condições em que os vírus podem ficar suspensos em gotículas no ar, ainda que por breves momentos, contaminando outrem via respiração ou mesmo como as modificações no meio ambiente propaladas pelos seres humanos, pode-se compreender como o SARS-CoV-2 contamina seres humanos.

A pandemia da COVID-19 provocou um confinamento de quase toda a humanidade, reduzindo as atividades industriais num espaço-tempo de sua disseminação que conduz a uma redução de emissões de gases e partículas responsáveis pelo aquecimento global e pela poluição local ou regional. Consequentemente, a qualidade do ar mudou, todavia, não as consequências positivas ou negativas da pandemia nestas questões em médio e longo prazos ainda não são conhecidas.

\subsection{Qualidade do ar}

A qualidade do Ar é avaliada em termos da concentração de poluentes em índices não naturais ou que interferem no ciclo natural da atmosfera de uma localidade ou região. As medições desses poluentes vêm sendo realizadas por equipamentos cada vez mais modernos, sendo atualmente utilizadas estações automáticas de monitoramento de qualidade do ar, com dados matemáticos analisados por computadores de última geração. Estas estações dispõem de sensores específicos, que determinam a concentração de vários poluentes em tempo real na atmosfera, armazenando os dados para serem transmitidos aos órgãos ambientais e divulgados à população, bem como para a construção da série histórica que busca entender as variações e como combater esta poluição.

A qualificação atmosférica é avaliada em função dos padrões definidos pela Organização Mundial da Saúde que parametrizou a definição dada pela Resolução do Conselho Nacional do Meio Ambiente (CONAMA) 491/2018. 
Art. $2^{\circ}$ Para efeito desta resolução são adotadas as seguintes definições: II - padrão de qualidade do ar: um dos instrumentos de gestão da qualidade do ar, determinado como valor de concentração de um poluente específico na atmosfera, associado a um intervalo de tempo de exposição, para que o meio ambiente e a saúde da população sejam preservados em relação aos riscos de danos causados pela poluição atmosférica; III - padrões de qualidade do ar intermediários - PI: padrões estabelecidos como valores temporários a serem cumpridos em etapas; IV - padrão de qualidade do ar final - PF: valores guia definidos pela Organização Mundial da Saúde - OMS em 2005 (CONAMA, 2018).

Os padrões de qualidade do ar são instrumentos de gestão, determinados pela concentração de um poluente específico na atmosfera que deve ser associado ao tempo de exposição, com vistas a preservar a saúde da população e o meio ambiente e compreender os motivos de aumento da concentração, ou não, dos poluentes que podem conduzir a doenças e modificações climáticas.

A Resolução CONAMA 491/2018 propõe que os padrões finais de qualidade do ar sejam aqueles baseados em padrões científicos internacionais definidos pela Organização Mundial da Saúde. No entanto, não estabelece prazos para alcançar, os padrões intermediários e finais, para cada poluente nem os valores desejáveis para a salvaguarda ambiental e humana. Esses padrões são referências para os níveis de concentração para cada poluente, que se ultrapassados poderiam colocar em risco a saúde da população. O conceito de poluição do ar advém desses limites quando ultrapassados. Segundo a Organização Mundial de Saúde (OMS) (2018):

A poluição do ar representa um importante risco ambiental para a saúde. Mediante a diminuição dos níveis da poluição do ar os países podem reduzir a carga de morbidade derivada de acidentes cerebrovasculares, canceres de pulmão e neomopatias crônicas e agudas, entre as quais asma. Quanto mais baixo seja a poluição do ar, melhor será a saúde cardiovascular e respiratória da população tanto a longo quanto a médio prazo. Segundo estimativas de 2016, a poluição do ar nas cidades e em zonas rurais, em todo o mundo, provoca anualmente 4,2 milhões de disfunções prematuras.

As estimativas da OMS apontam que a maioria dos óbitos prematuros ocorridos em 2016, relacionadas com poluição do ar, foram de acidentes cardiovasculares, infecções pulmonares e câncer de pulmão. Todavia, muitas dessas mortes podem ser atribuídas a mais de um fator de risco ao mesmo tempo, como o indivíduo ser fumante ou estar em um ambiente de fumantes e ambientes insalubres (OMS, 2018), mas não se pode desconsiderar o impacto do meio ambiente nessas mortes, pois se há um crescimento exacerbado de determinada doença em determinada região, o fator 
ambiental pode ter interferido e por isso precisa ser investigado.

Nesse sentido, é de suma importância monitorar a qualidade do ar para determinar o nível de concentração de poluentes, em função dos efeitos ambientais que são capazes de produzir.

Nesse sentido leciona Priscila Kelly Moreira Ireno (2015, p.7)

Utilizam-se os monitoramentos da qualidade do ar, principalmente para medir o grau de exposição dos receptores (seres humanos, animais, plantas e materiais) em regiões propicias a um maior grau de concentração de poluentes, dos quais são baseados nas concentrações máximas e mínimas definidas pela Resolução CONAMA 03/90, que quando ultrapassadas poderão afetar a saúde e o bem estar da população. Para tanto, são realizados programas de monitoramento desenvolvidos pelos estados, de acordo com as atribuições da legislação supracitada. E tem como principais metas, identificar as possíveis tendências de poluição em uma região, tomar medidas emergenciais em episódios críticos, de forma assegurar a saúde da população exposta e garantir o controle dos poluentes tóxicos atmosféricos introduzidos por atividades antrópicas.

Assim sendo, os programas de monitoramento da qualidade do ar visam assegurar à população a manutenção de padrões em níveis que assegurem a saúde e a preservação ecossistêmica. Vale ressaltar que a resolução CONAMA 03/90 foi revogada pela Resolução 491/2018, que, depois de décadas de debates, atualizou conceitos e referências, tendo como base recomendações da OMS e experiências internacionais, ainda que, como citado, não estabeleceu prazos para o atingimento das metas necessárias à salvaguarda da saúde humana e do meio ambiente em geral.

A competência para o monitoramento da qualidade do ar é dos órgãos ambientais estaduais, com base nos poluentes e procedimentos estabelecidos na resolução CONAMA 491/2018, calculando e divulgando o Índice de Qualidade do Ar (IQA), com a finalidade de informar a população de maneira clara e objetiva sobre as condições do ar que respiram.

Esse índice, adotado internacionalmente, foi desenvolvido pela Agência de Proteção Ambiental dos Estados Unidos da América (EPA), ferramenta que visa transformar as concentrações dos poluentes dispersos em valores que viabilizam a comparação com os padrões estabelecidos pelas legislações. A transformação das concentrações em índices é obtida por cálculo específico para cada poluente monitorado. (IRENO, 2015). Seu estudo na atualidade é essencial para garantia da sadia qualidade de vida, e sua divulgação propicia a informação para que a sociedade civil se organize para garantir um meio ambiente adequado à vida. 


\subsection{Principais poluentes e fontes de emissões}

O controle dos principais poluentes, considerados nas políticas públicas para a proteção ambiental, tem como principal foco a saúde da população. Entretanto, também se refere à proteção da fauna e da flora, do desenvolvimento socioeconômico e do patrimônio natural, histórico, cultural e paisagístico.

[...] poluente atmosférico: qualquer forma de matéria em quantidade, concentração, tempo ou outras características, que tornem ou possam tornar o ar impróprio ou nocivo à saúde, inconveniente ao bem-estar público, danoso aos materiais, à fauna e flora ou prejudicial à segurança, ao uso e gozo da propriedade ou às atividades normais da comunidade (CONAMA, 2018).

Os poluentes atmosféricos se dividem em dois grandes grupos: partículas e gases, existindo, ainda, a classe "fumaças", que ocorre quando se verificam partículas dissolvidas em gases.

No caso de partículas, atualmente a principal atenção se volta para as partículas inaláveis, sabendo que quanto menores mais profundamente podem atingir o aparelho respiratório dos seres humanos. Assim temos as partículas menores que 10 micrômetros expressas como $\mathrm{PM}_{10}$ e as menores que 2,5 micrômetros, expressas como $\mathrm{PM}_{2,5}$.

Material Particulado $\mathrm{MP}_{10}$ : partículas de material sólido ou líquido suspensas no ar, na forma de poeira, neblina, aerossol, fuligem, entre outros, com diâmetro aerodinâmico equivalente de corte de 10 micrômetros;

Material Particulado $\mathrm{MP}_{2,5}$ : partículas de material sólido ou líquido suspensas no ar, na forma de poeira, neblina, aerossol, fuligem, entre outros, com diâmetro aerodinâmico equivalente de corte de 2,5 micrômetros (CONAMA, 2018).

No caso dos gases são destacados o monóxido de Carbono (CO), dióxido Enxofre (SO2), dióxido de Nitrogênio (NO2) e Ozônio (O3).

No Brasil os padrões de qualidade do ar são estabelecidos pela Resolução CONAMA n. 491/2018 e esta dispôs padrões para partículas, gases e presença de Chumbo $(\mathrm{Pb})$ na atmosfera, que devem ser monitorados pelos órgãos ambientais estaduais. De acordo com o Ministério do Meio Ambiente do Brasil (MMA),

Os parâmetros regulamentados pela legislação ambiental são os seguintes: partículas totais em suspensão (PTS), fumaça, partículas inaláveis $\left(\mathrm{MP}_{10}\right.$ e $\left.\mathrm{MP}_{2,5}\right)$, dióxido de enxofre $\left(\mathrm{SO}_{2}\right)$, monóxido de carbono $(\mathrm{CO})$, ozônio $\left(\mathrm{O}_{3}\right)$, dióxido de nitrogênio $\left(\mathrm{NO}_{2}\right)$ e chumbo (PB). A mesma resolução estabelece ainda os critérios para episódios 
agudos de poluição do ar. Ressalte-se que a declaração dos estados de Atenção, Alerta e Emergência requer, além dos níveis de concentração atingidos, a previsão de condições meteorológicas desfavoráveis à dispersão dos poluentes. (MMA, 2020a).

Os novos padrões determinados, com validade a partir da publicação dessa resolução, 21 de novembro de 2018, foram um pouco mais restritivos daqueles que vigoravam desde 1990. Todavia, não foram determinados novos prazos intermediários e nem mesmo o prazo final para se atingirem os níveis recomendados pela OMS desde 2005.

As fontes de emissão de poluentes atmosféricos podem ser naturais ou antrópicas, produzidas pelas atividades humanas, e as fontes antrópicas se dividem em fixas ou móveis, sendo emitidas de forma pontual ou fugitiva.

A Fundação Estadual do Meio Ambiente (FEAM) (2015) define:

As fontes de emissão podem ser naturais (vulcões) ou antrópicas (produzidas pelo homem). As principais fontes antrópicas de poluentes atmosféricos são denominadas fontes fixas (indústrias) ou móveis (veículos a gasolina/diesel/álcool/gás natural), podendo ser decorrentes da combustão externa (caldeiras, fornos) ou combustão interna (automóveis) e outros processos de transformação (fabricação de ácidos). Essas fontes podem ser também pontuais (chaminés, dutos) ou difusas (não pontual e aleatórias, isto é, não têm um ponto de lançamento específico ou não advêm de um ponto preciso de geração. As emissões das fontes difusas denominam-se fugitivas.

Sendo assim, considera-se fonte de emissão antrópica fixa o ponto do qual são dispersados poluentes para a atmosfera, sendo fixa a instalação ou equipamento, como, por exemplo, chaminés de indústrias; ou móveis, emissões provenientes de veículos automotores. Há que se considerar, ainda, as fugitivas como sendo aquelas por arraste eólico.

As principais fontes para esses poluentes atmosféricos são as emissões da queima de combustíveis fósseis em processos industriais, geração de energia (termelétricas) e por veículos automotores. Ressalta-se que os vários processos da indústria extrativista e de transformação, em função das matérias primas e tecnologias utilizadas, apresentam outras fontes de poluentes, além da queima de combustíveis fósseis, como por exemplo, emissões de material particulado e gases em fornos de cimento e siderurgia e arraste de material particulado em mineração a céu aberto.

Vale ressaltar que nos grandes centros urbanos, as emissões provenientes de fontes móveis são responsáveis por grande parcela da poluição atmosférica. Ainda que a tecnologia automobilística tenha mitigado os efeitos nocivos provenientes da combustão dos motores, os veículos 
produzem quantidade prejudicial de material particulado. Conforme expõe a FEAM (2020) ao discorrer sobre fontes móveis:

O tráfego de veículos é um dos grandes responsáveis pela degradação da qualidade do ar nos centros urbanos, onde a maior parte da população mundial vive hoje. Ainda que a emissão dos veículos tenha sofrido grande redução a partir de diversas melhorias tecnológicas nos motores e alterações nos combustíveis, as emissões de poluentes atmosféricos provenientes da frota ainda constituem um fator que merece atenção, principalmente devido ao crescimento da frota circulante nas áreas urbanas e às condições de tráfego.

Apesar de, individualmente, esse tipo de emissão ser aparentemente insignificante, ao se analisar o número de veículos existentes nas grandes cidades, verifica-se a geração de toneladas de poluentes por dia. Diversos fatores influenciam o montante da emissão de veículos nas áreas urbanas como os tipos de veículos, a idade da frota, o tipo de combustível, a quantidade de veículos circulantes e as condições do trânsito.

Muitas dessas emissões, além de interferir na saúde e na qualidade do ar em curto prazo, participam da composição mundial de emissões que contribuem para as mudanças climáticas em curto, médio e longo prazo, o que demonstra o desvincular ético da sociedade para com o ambiente em que vive.

\subsection{Efeito estufa e aquecimento global}

O Efeito Estufa é um fenômeno natural que é essencial por possibilitar as condições necessárias para a vida no planeta. Quando a radiação solar (luz) é incidida sobre a terra, aquela é refletida em forma de radiação infravermelha (calor), e parte vai para o espaço e parte é retida por gases presentes na atmosfera, os Gases de Efeito Estufa (GEE). Os principais GEE são dióxido de Carbono $\left(\mathrm{CO}_{2}\right)$, metano $\left(\mathrm{CH}_{4}\right)$ e vapor d'água $\left(\mathrm{H}_{2} \mathrm{O}\right)$, responsáveis por manterem uma temperatura média na Terra de cerca de $15^{\circ} \mathrm{C}$ positivos, permitindo o desenvolvimento da vida no nosso planeta (BRANCO, 1982).

O efeito estufa é um fenômeno natural e possibilita a vida humana na Terra.

Parte da energia solar que chega ao planeta é refletida diretamente de volta ao espaço, ao atingir o topo da atmosfera terrestre - e parte é absorvida pelos oceanos e pela superfície da Terra, promovendo o seu aquecimento. Uma parcela desse calor é irradiada de volta ao espaço, mas é bloqueada pela presença de gases de efeito estufa que, apesar de deixarem passar a energia vinda do Sol (emitida em comprimentos de onda menores), são opacos à radiação terrestre, emitida em maiores comprimentos de onda. Essa diferença nos comprimentos de onda se deve às diferenças nas 
temperaturas do Sol e da superfície terrestre. De fato, é a presença desses gases na atmosfera o que torna a Terra habitável, pois, caso não existissem naturalmente, a temperatura média do planeta seria muito baixa, da ordem de $18^{\circ} \mathrm{C}$ negativos. A troca de energia entre a superfície e a atmosfera mantém as atuais condições, que proporcionam uma temperatura média global, próxima à superfície, de $14^{\circ} \mathrm{C}$. (MMA, 2012).

Historicamente, as condições de calor da superfície terrestre apresentaram-se disformes; períodos mais quentes se intercalaram com outros menos quentes ou glaciais ao longo do tempo. Todavia, na atualidade existe a preocupação pela interferência de atividades humanas, que liberam GEE, que podem estar potencializando o Efeito Estufa natural. Assim, essa variação de temperatura, mesmo sendo de origem natural, pode estar sendo acelerada pela interferência humana no ambiente e o tema tem se destacado em discussões globais. (MENDONÇA, 2003).

O clima tem apresentado mudanças ao longo da história do Planeta. No entanto, é possível perceber que a mudança climática atual apresenta particularidades. Em 2005, a presença de dióxido de carbono $\left(\mathrm{CO}_{2}\right)$ na atmosfera excedeu a variação natural dos últimos 650 mil anos, atingindo o recorde de 379 partes por milhão em volume (ppm), o que significa um aumento de quase 100 ppm desde a era pré-industrial. (MMA, 2012). Esta, entre outras, grandes discrepâncias fizeram com que se observasse a impossibilidade de esta drástica mudança ser proveniente, exclusivamente, de fenômenos naturais, passando-se a analisar a interferência antrópica no meio ambiente como fator influenciador na mudança do clima.

Dentre as atividades humanas que mais têm contribuído para o aquecimento global destaca-se a queima de combustíveis fósseis, sendo a China e os Estados Unidos os maiores emissores de $\mathrm{CO}_{2}$. Já no caso do Brasil, a mudança do uso do solo, principalmente os desmatamentos, constitui os principais emissores que contribuem para as mudanças climáticas (IPCC, 2014).

Outro fator que indica a mudança climática é o aumento da temperatura média global do ar e dos oceanos, que vem provocando o derretimento das calotas polares e a elevação do nível do mar. As temperaturas médias globais da superfície são as maiores dos últimos cinco séculos, houve um aumento de cerca de $0,74^{\circ} \mathrm{C}$, nos últimos cem anos. Caso as interferências antrópicas não sejam mitigadas, espera-se observar, ainda neste século, um clima bastante incomum que poderá apresentar, por exemplo, um acréscimo médio da temperatura global de $2^{\circ} \mathrm{C}$ a $5,8^{\circ} \mathrm{C}$ (MMA, 2012). 
Dessa forma, as interferências humanas devem ser mitigadas para que as condições normais do planeta possam ser reestabelecidas. Para isso é necessária a cooperação internacional para a adoção de medidas que minimizem os impactos ambientais. Em 1992, durante a Conferência do Rio foi criada a Convenção - Quadro das Nações Unidas sobre Mudanças Climáticas, entrando em vigor em 1994, contando atualmente com 195 países. Este Tratado tem como objetivo promover a cooperação internacional para estabilizar o sistema climático global e conter o aquecimento da temperatura do planeta provocado pela emissão de GEE. (REI; GONÇALVES; SOUZA, 2017).

Os países membros se reúnem anualmente em Convenções das Partes (COP), sendo a última, COP 25, realizada em novembro de 2019 em Madri. Dentre as COP, destaca-se, incialmente, a COP 3, realizada em 1997 na cidade de Kyoto (Japão), quando foi firmado o Protocolo de Kyoto, com metas para os países desenvolvidos reduzirem suas emissões, em média, de 5,2\% em relação aos níveis de 1990, até 2012. O Protocolo fracassou em sua missão, pois os resultados não foram alcançados, especialmente pelo não envolvimento dos principais países emissores de GEE. Outro destaque digno de nota foi a COP 21 realizada em 2015 em Paris, que deu origem ao Acordo de Paris, quando os países signatários se comprometeram a estabelecerem suas contribuições nacionais determinadas (NDC) ${ }^{5}$, com entrada em vigor a partir de 2020. Apesar de bem menos rígida que o Protocolo de Kyoto, o Acordo de Paris envolveu todos os países de forma basicamente igualitária e numa tentativa de esforços comuns em cumprimento ao princípio da Cooperação entre os povos, emanada da Convenção de Estocolmo de 1972.

O Brasil assumiu metas de reduzir 37\% das emissões de GEE até 2025 e de $43 \%$ até o ano de 2030, ampliando a participação de fontes de energia renováveis na matriz energética, além de reduzir a zero o desmatamento ilegal na Amazônia brasileira.

No entanto, ainda existem aqueles que não acreditam na possibilidade de as interferências humanas serem capazes de provocar as mudanças climáticas, os chamados "céticos do clima", que se baseiam em estudos científicos que acreditam especialmente em miniciclos glaciais que podem ocorrer no planeta de forma rápida ${ }^{6}$ e que não têm relação com as emissões

5 Nationally Determined Contribution

6 Para mais informações sobre o tema ler História geológica e Ciência do clima: métodos e origens do estudo dos ciclos climáticos na Terra Marcos José de Oliveira, Gustavo Macedo de Mello Baptista, Celso Dal Ré Carneiro e Francisco Arthur Silva Vecchia. 
humanas. Tais pesquisas provavelmente influenciam os Estados Unidos, segundo maior emissor de GEE, a não participar de nenhum acordo mundial de combate às modificações climáticas, como foi no Protocolo de Kyoto e sua saída do Acordo de Paris.

A COP 26, prevista para se realizar em novembro de 2020 no Reino Unido, por conta da Pandemia da COVID 19 foi adiada para 2021 e já tem os temas a serem analisados e discutidos divulgados na página do IPCC ${ }^{7}$.

\section{COVID-19: IMPACTOS NA ATMOSFERA NA QUALIDADE DO AR}

O cenário mundial atual é caracterizado pela existência de uma Pandemia, um surto viral originado na cidade de Wuhan-China, com uma propagação epidemiológica de velocidade de transmissão muito rápida, de forma que em cerca de três meses já havia um surto mundial que levou governos a restringirem o direito de locomoção e o livre exercício econômico, perante os riscos de contaminação. Diante disso, faz-se necessária a compreensão histórica do surgimento das medidas não farmacológicas que visam mitigar os efeitos do surto viral.

Já na Grécia Antiga, Hipócrates, no século V a.C., definiu que, para se verificar se uma doença era crônica ou proveniente de agente patogênico o isolamento deveria ser mantido por quarenta dias. O termo quarentena é derivado da expressão italiana "quarenta giorni", que significa quarenta dias, datado de 1377, época em que a Europa sofreu com o surto da peste negra. Diante da possibilidade de propagação da doença, os navios deveriam permanecer quarenta dias ancorados após a chegada no porto da República de Ragusa, antiga colônia de Veneza, prática que foi disseminada para outros portos da Itália e da França no século seguinte. Além disso, o uso da quarentena na saúde também foi registrado no século XVIII, quando o governo britânico a utilizou como medida de controle do surto de peste bubônica (UCHÔA, Silvia; UCHÔA, Bruno, 2020).

Com o estreitamento das relações entre os estados nacionais e o comércio internacional intenso, a saúde pública se tornou uma preocupação internacional que necessitou ser regulamentada, tendo em vista a grande circulação de pessoas, bens e mercadorias por todos os países. O temor de possíveis disseminações de doenças levou a Convenção Sanitária Internacional realizada em 1926 a discutir a quarentena como medida possível

7 Site do IPCC: https://www.ipcc.ch/reports/. 
para o controle de enfermidades. O regulamento Sanitário Internacional definiu o conceito de emergência de saúde pública de importância internacional. Este é um evento extraordinário e transfronteiriço que coloca em risco a saúde pública e que exige respostas coordenadas. (LIMA; COSTA, 2015).

A Organização Mundial de Saúde (OMS) com intuito de organizar os esforços no combate a emergências médicas pandêmicas internacionais de Influenza, já nesse século, instituiu medidas farmacológicas e não farmacológicas a serem adotadas. Lima e Costa (2015, p.11) lecionam:

Para controlar emergências em pandemias de influenza, a Organização Mundial de Saúde (OMS) estabeleceu estratégias de intervenções farmacêuticas e nãofarmacêuticas, a serem iniciadas na descoberta de surto, além de questões éticas para serem observadas durante a aplicação das medidas. As intervenções não farmacêuticas incluem atenção aos hábitos de higiene, medidas restrição de liberdade, como o isolamento de pessoas doentes, quarentena de contatos, medidas de distanciamento social, como restrição de viagens, fechamento de escolas e locais de aglomeração.

As medidas não farmacológicas buscam reduzir a velocidade de propagação da epidemia viral, compreendendo medidas de higiene e restritivas de locomoção, que impõem à população o não exercício de atividades cotidianas como circulação em vias públicas, viagens, comércio e produção industrial. Dessa forma, há uma tentativa de reduzir a taxa de velocidade de transmissão viral, para que o sistema de saúde não fique sobrecarregado. (OLIVEIRA, 2020).

A Organização Mundial de Saúde no Regulamento Sanitário Internacional ${ }^{8}$ definiu no artigo primeiro quarentena e isolamento da seguinte maneira:

\footnotetext{
"Quarentena" significa a restrição das atividades e/ou a separação de pessoas suspeitas de pessoas que não estão doentes ou de bagagens, contêineres, meios de transporte ou mercadorias suspeitos, de maneira a evitar a possível propagação de infecção ou contaminação; "isolamento" significa a separação de pessoas doentes ou contaminadas ou bagagens, meios de transporte, mercadorias ou encomendas postais afetadas de outros, de maneira a evitar a propagação de infecção ou contaminação (OMS, 2005).
}

Dessa forma, a quarentena seria a restrição de atividades, de pessoas e objetos que possivelmente possam estar contaminados pela enfermidade; já o isolamento seria a segregação de bens contaminados ou pessoas

8 O Regulamento Sanitário Internacional (RSI) é um instrumento jurídico internacional vinculativo para 196 países em todo o mundo, que inclui todos os Estados Membros da Organização Mundial da Saúde (OMS). Seu objetivo é ajudar a comunidade internacional a prevenir e responder a graves riscos de saúde pública que têm o potencial de atravessar fronteiras e ameaçar pessoas em todo o mundo. 
doentes; por sua vez, o distanciamento social é a limitação das atividades cotidianas que envolvam aglomerações de pessoas, com o fechamento de escolas, restrição de viagens, comércio e indústria.

Segundo alguns autores como Schuchmann et al. (2020), a quarentena e o isolamento possuem efetividade, pois torna possível identificar as pessoas que estão contaminadas ou suspeitas de contaminação rastreando onde e como tiveram contato com objetos e indivíduos contaminados. Não sendo possível essa identificação, a medida a ser adotada é a contenção comunitária para minimizar o contato interpessoal na localidade afetada para se construir o histórico do ciclo de contaminação. A contenção comunitária contempla duas formas distintas: a horizontal (supressão) e vertical (mitigação), sendo esta, apenas a separação dos doentes e dos cidadãos que constituem grupo de risco e aquela uma restrição total de circulação de pessoas devendo ser exercidas apenas as atividades essenciais.

No entanto, no Brasil, o termo isolamento vem sendo utilizado de forma geral, considerando isolamento vertical a restrição de circulação dos doentes e das pessoas que apresentam características que configuram fator de risco em caso de contágio, visando mitigar a propagação da doença; e, por sua vez, o isolamento horizontal o que não faz nenhuma distinção aplicando-se as restrições a todos os cidadãos, com a paralisação total dos fluxos de deslocamento (lockdown).

Como visto, em 2020, o surto da Covid-19 obrigou os Estados a adotarem medidas para contenção da propagação do vírus. Assim, seguindo diretrizes da Organização Mundial da Saúde, os países deveriam adotar as medidas não farmacológicas adequadas à realidade local, até pela, ainda atual, indefinição de qual seria a possibilidade farmacológica de proteger contra o vírus SARS-CoV-2.

Nesse sentido, aduz a Organização Mundial da Saúde (OMS, 2020):

En función de las respuestas a las tres preguntas, se asignará un nivel de riesgo (alto, intermedio o bajo). En este contexto, el riesgo es una valoración general de las consecuencias negativas que puede conllevar relajar las medidas y la capacidad de gestionarlas. El nivel de riesgo puede orientar la adaptación de las medidas de salud pública y sociales. En el marco de la pandemia de COVID-19, la identificación, la realización de pruebas de detección y el aislamiento de casos, el rastreo de contactos y la cuarentena son medidas de salud pública básicas en todas las etapas de la respuesta. De igual modo, las medidas encaminadas a garantizar la protección de los trabajadores sanitarios y los grupos vulnerables deben mantenerse. Dependiendo del nivel de riesgo, se deberán adaptar otras medidas, como las medidas comunitarias, la restricción de concentraciones multitudinarias y las medidas para reducir el riesgo de introducción del virus. 
Dessa maneira, as nações tiveram de adaptar as medidas de saúde à realidade de seus territórios para que fossem efetivas no combate à propagação do surto viral. Quando anunciado pela OMS, o surto viral de importância internacional, o governo brasileiro para controle da doença, através da Lei n. 13.979 de 06 de fevereiro de 2020, impôs regras de limitações e restrições, dispondo "sobre as medidas para enfrentamento da emergência de saúde pública de importância internacional decorrente do corona vírus responsável pelo surto de 2019”.

Art. $3^{\circ}$. Para enfrentamento da emergência de saúde pública de importância internacional decorrente do coronavírus, as autoridades poderão adotar, no âmbito de suas competências, dentre outras, as seguintes medidas: a) entrada e saída do País; b) locomoção interestadual e intermunicipal. (BRASIL, 2020).

Tal indicação legal como se pode perceber, foi genérica e não realizou um programa de integração nacional de combate a pandemia, gerando os resultados percebidos na atualidade.

Diante das dificuldades de se separarem as pessoas doentes das pessoas saudáveis, principalmente face ao baixo nível de testagem no País, a medida de contenção comunitária adotada na maioria dos entes federativos foi o isolamento, para garantir o atendimento hospitalar dos acometidos pelo vírus. Sendo assim, a redução de circulação de pessoas, bens e serviços no território nacional vem ocasionando a mitigação das emissões atmosféricas e, consequentemente, do aquecimento global e da poluição atmosférica local e regional, já que as fontes foram reduzidas.

\subsection{COVID-19 e qualidade do ar}

O isolamento decorrente da Pandemia da COVID-19 restringiu, além da mobilidade de pessoas, bens e serviços, a paralisação de muitas atividades de produção responsáveis por emissões atmosféricas além dos GEE. Assim, emissões de material particulado $\left(\mathrm{PM}_{10}\right.$ e $\left.\mathrm{PM}_{2,5}\right)$, gases de enxofre $\left(\mathrm{SO}_{2}\right)$, de nitrogênio $\left(\mathrm{NO}_{2}\right)$ e ozônio $\left(\mathrm{O}_{3}\right)$, principais poluentes que degradam a qualidade do ar nos níveis local e regional, também apresentaram reduções, contribuindo para a melhoria da qualidade do ar, de forma generalizada no mundo todo. Além disso, a baixa circulação reduziu os GEE que contribuem para as modificações climáticas no espaço de tempo de isolamento estabelecido em cada país.

Poucas não foram as notícias na mídia internacional da melhoria da 
qualidade do ar em cidades na China e na Europa, conduzindo a reflexão sobre o papel da humanidade na piora ambiental e sobre o respeito ao meio ambiente que abriga os seres humanos.

De acordo com Marco Hernandez, materiais particulados identificados pela sigla PM2.5 - que têm a capacidade de, através dos pulmões, entrar na corrente sanguínea e desencadear problemas de saúde como o câncer, acidentes vasculares cerebrais e cardiopatias, liberados na atmosfera principalmente a partir da queima de combustíveis, sofreram grandes quedas na província de Hubei, na China, após a imposição de restrições na circulação de veículos na quarentena (TAMANINI, 2020). Os "lockdowns" - suspensão total de atividades - realizados em alguns países da Europa como medida de contenção aos efeitos da pandemia do novo coronavírus tiveram um papel importante para diminuir significativamente os níveis de poluição em todo o continente, segundo a Agência Espacial Europeia. A agência informou que os níveis de dióxido de nitrogênio caíram cerca de 50\% em algumas cidades, com a queda coincidindo com as "rigorosas medidas de quarentena implementadas em toda a Europa. As melhorias na qualidade do ar foram mais evidentes na França, Espanha e Itália, países que determinaram um confinamento rigoroso por várias semanas. Paris teve uma queda de 54\% nas concentrações de dióxido de nitrogênio ao comparar o período entre 13 de março e 13 de abril com o mesmo período de 2019. Já Madri, Milão e Roma registraram quedas de cerca de 45\%. (POLUIÇÃO..., 2020).

No Brasil, também foi possível observar reduções nos níveis de poluentes e melhora na qualidade do ar em várias capitais, decorrentes das medidas de isolamento social. Em São Paulo, por exemplo, foi registrada uma importante queda nos índices de monóxido de carbono, que atingiram os menores índices para a época, caindo para 1 parte por milhão contra os 9 ppm habituais (CETESB, 2020).

Além disso, outras melhoras advindas dessas restrições também foram constatadas pela CETESB em divulgação do site oficial do governo estadual:

Desde 20 de março, a Companhia Ambiental do Estado de São Paulo (CETESB) tem registrado, em todas as 29 estações de monitoramento da região, qualidade do ar boa para os poluentes primários, aqueles emitidos diretamente pelas fontes poluidoras. Além do menor número de veículos em circulação, as condições mais livres do trânsito e a ausência de engarrafamentos também contribuem para uma menor emissão de poluentes. A companhia esclarece que a qualidade do ar também é fortemente influenciada pelas condições meteorológicas de dispersão dos poluentes. (SÃO PAULO, 2020).

O Instituto Estadual do Meio Ambiente do Rio de Janeiro (INEA) também constatou melhora no índice de qualidade do ar entre março e maio de 2020. Na região metropolitana do Rio de janeiro os níveis de dióxido 
de nitrogênio $\left(\mathrm{NO}_{2}\right)$ no ar diminuíram bastante, com índices de redução de $77 \%$ e $45 \%$ no Distrito Industrial de Santa Cruz e em Duque de Caxias respectivamente (INEA, 2020).

Com a aplicação das medidas de isolamento, a FEAM verificou uma melhora expressiva na qualidade do ar em Belo Horizonte com uma redução na emissão de partículas inaláveis, conforme aduz:

De acordo com a equipe da Gerência de Monitoramento da Qualidade do Ar e Emissões (Gesar), da Feam, a paralisação, restrição, suspensão e redução de algumas atividades, com destaque para as atividades industriais e a circulação de veículos, contribuiu diretamente para a redução das emissões atmosféricas. Para verificar os níveis dessas emissões, a Gesar verificou os dados de estações em Belo Horizonte, cujo perfil da poluição aponta para a predominância das vias de tráfego como principal grupo das fontes emissoras, e também de Ibirité e Betim, este último fortemente influenciado pela atividade industrial como principal atividade poluidora. (FEAM, 2020).

Diante dessas melhorias noticiadas, buscou-se acompanhar no período de 03 a 18 de junho de 2020, além dos boletins diários de qualidade do ar das cidades de São Paulo, Rio de Janeiro e Belo Horizonte, os boletins de grandes metrópoles internacionais como Londres, Paris e Nova York.

A pesquisa da qualidade do ar em várias cidades do mundo foi feita pelo sítio eletrônico Aqinc.org ${ }^{9}$. Para o período pesquisado, os boletins dessas cidades apresentaram IQA bom durante a maior parte dos dias, ocorrendo alguns períodos de qualidade regular.

Assim, pode-se observar que o isolamento e a paralisação de muitas atividades decorrentes da pandemia da COVID-19 vêm contribuindo para a melhoria da qualidade do ar em diversas localidades e regiões.

Faz-se mister ressaltar, que a par dessas contribuições positivas, o novo coronavírus pode ficar presente em gotículas suspensas no ar por algum tempo, resultante do processo de respiração de pessoas contaminadas, com potencial de contaminação de outrem. Esse tempo de suspensão do vírus no ar ainda tem sido objeto de muitas discussões e pesquisas, que apontam diversas variáveis para sua determinação, como ambiente fechado ou aberto, temperatura, umidade, correntes de vento e velocidade de deslocamento das pessoas contaminadas.

Mas não se pode negar que, nesse espaço de tempo de isolamento por causa do SARS-Cov-2, foi possível refletir sobre a redução de poluição, ou como os seres humanos estão interferindo no meio ambiente ou a conduta de tratamento prática ou moral dada ao mundo natural. Apesar de ainda ser

9 Disponível em: https://aqinc.org/city/. 
incerto o motivo de início da pandemia, a teoria central seria de transmissão de animais silvestres para o ser humano.

\subsection{COVID-19 e o aquecimento global}

Desde a identificação do vírus SARS-CoV-2, sigla do inglês Severe Acute Respiratory Syndrome Coronavirus 2, na cidade de Wuhan, província de Hubei na China, provavelmente originário de um mercado de animais silvestres, à época denominado novo coronavírus 2019, observou-se seu alto poder de contágio, causando a doença denominada COVID-19.

No dia 31 de dezembro de 2019, a Organização Mundial da Saúde (OMS) foi informada de vários casos pouco usuais de pneumonia em Wuhan, capital da Província de Hubei na China. No dia 7 de janeiro de 2020 foi identificado e confirmado um novo coronavírus (SARS-CoV-2), pertencente a mesma família que já tinha ocasionado as epidemias de SARS (Severe Acute Respiratory Syndrome) e de MERS (Middle East Respiratory Syndrome) (SILVA et al., 2020, p. 3).

Segundo Acosta et al. (2020), a família do coronaviridae tem quatro gêneros, mas apenas dois podem causar doenças em humanos e estes têm sete cepas virais. No entanto, apenas quatro cepas vinham causando doenças, que hoje causam sintomas leves, nos seres humanos. As três cepas mais recentes têm causado doenças com sintomas mais severos e alta mortalidade: a MERS-CoV, a SARS-CoV-1 e na atualidade a SARS-CoV-2.

A doença se espalhou pela Europa, Ásia, Estados Unidos, Austrália, América Latina e África, tornando-se uma Pandemia de rápida transmissão, causando muitos óbitos em pouco espaço de tempo, levando o pânico a muitas regiões. Para minimizar os riscos de contágio, as primeiras orientações foram para a quarentena e o isolamento. Este para as pessoas evitarem contatos, principalmente os chamados grupos de risco, e aquela para as pessoas já contaminadas.

Essas orientações defendidas pela OMS e pela maioria dos infectologistas ocasionaram uma redução significativa de mobilidade de pessoas, bens e serviços no planeta, contribuindo para a paralisação de vários modais de transporte, reduzindo consequentemente o consumo de combustíveis fósseis e a emissão de GEE.

O fechamento de fábricas e do comércio, além das restrições de viagem para lidar com a disseminação do vírus resultou em redução nas emissões de $\mathrm{CO} 2$, no uso de combustíveis fósseis, na geração de resíduos e uso de matéria prima, segundo cálculos de Lauri Myllyvirta, do Centro de Pesquisa em Energia e Ar Limpo (CREA) com sede nos Estados Unidos (OLIVEIRA; CAMPOS; SIQUEIRA, 2020). 
Para diminuir a transmissão desse novo coronavírus, muitos países fecharam suas fronteiras, com voos internacionais e domésticos cancelados. Muitas atividades fecharam as portas, gerando desemprego e impactando negativamente o PIB. "Para cada mês, haverá uma perda aproximada de $2 \%$ de pontos no crescimento anual do PIB. Só o sector do turismo enfrenta um decréscimo de produção que pode ir de 50\% a 70\%." (CHACKABORTY; PRASENJIT, 2020).

A redução das emissões de GEE já vinha sendo considerada uma necessidade imperiosa para reter o aumento do aquecimento global, mas as diversas estratégias adotadas em fóruns internacionais ainda não vinham apresentando os resultados esperados. O que ninguém poderia imaginar é que seria o surgimento de um novo vírus que obrigaria o mundo a desacelerar provocando essa redução, ainda que com altos custos humanitários e econômicos. Contudo, em longo prazo pode conduzir a discussão da efetividade de reduzir essas emissões com menos impactos, se programada e realizada de forma coordenada e coletiva pela comunidade mundial, gerando uma nova revolução na relação com o meio ambiente, que pode ter novas regras de conduta como pensado por Taylor (1981).

Segundo Lauri Myllyvirta (2020), pesquisador do Centre for Research on Energy and Clean Air (CREA), as emissões de $\mathrm{CO}_{2}$ da China, maior emissor mundial de GEE, no mês de maio de 2020 ficaram 6\% abaixo dos níveis emitidos em maio de 2019.

No caso do Brasil, conforme já mencionado, o principal fator de emissões de $\mathrm{CO}_{2}$ para a atmosfera é a mudança do uso do solo, notadamente o desmatamento ilegal na Amazônia. Nesse caso, a Pandemia COVID-19 não surtiu efeitos de redução; ao contrário, as previsões para os dados de desmatamento na Amazônia são de contínuo crescimento, devido também à mudança emergencial de foco para a redução da pandemia e seus impactos na saúde.

O monitoramento do desmatamento na Amazônia é realizado por um sistema de satélites, denominado PRODES, que apresenta seus resultados anualmente para períodos que se encerram no mês de julho. Assim, ainda não estão disponíveis os dados para o período da pandemia. Todavia, outro sistema criado para dar alertas sobre os desmatamentos e apoiar a fiscalização dos órgãos ambientais, o DETER, também operado pelo INPE, permite observar o aumento de focos de desmatamento $\left(4.090,28 \mathrm{~km}^{2}\right)$ até meados de julho de 2020 (INPE, 2020).

A avaliação acurada dos efeitos da Pandemia sobre o aquecimento 
global, somente será possível com o próximo relatório do Painel Intergovernamental sobre Mudanças Climáticas (IPCC), integrante do Programa das Nações Unidas para o Meio Ambiente (PNUMA), previsto para 2021 e que foi responsável por divulgar informações sobre os riscos do aquecimento global, em um último relatório foi publicado em 2014.

\subsection{O que esperar no pós-pandemia para a poluição atmosférica}

Como demonstrado, no momento pandêmico da COVID-19 iniciado em dezembro de 2019 e que se mantém até o presente momento, muitas discussões em torno da relação do ser humano com a natureza, a tecnologia, a coletividade, a economia e os outros seres humanos foram realizadas. Acosta et al. (2020, p. 202), por exemplo, afirmam:

\footnotetext{
A aplicação do conceito de saúde planetária viabiliza meios para um novo modelo de desenvolvimento, um em que as tendências mais marcantes sejam impulsionadas por forças da equidade, do equilíbrio e da eficiência, construídas com respeito pela integridade dos sistemas naturais, pela ética no convívio entre pessoas e, sobretudo, com a percepção de que o planeta e todos seus componentes - seres e sistemas - são inexoravelmente interconectados e compartilham destino comum.
}

O que se espera é uma mudança em relação a estes temas, pois a forma atual de utilizar a biodiversidade é exploratória de tal forma que começa a pôr em risco a existência humana. A esperança é que ao se compreender o impacto humano no planeta, que pode ser pensada pela abstenção da realização de atividades por este espaço de tempo, possa ser repensada a relação ser humano natureza, pois verificou-se que a natureza pode se recuperar na ausência de humanos e que é possível ter uma relação mais ética e moral entre as partes evocando Taylor (1981) na necessidade de o ser humano pensar em se comprometer com certos princípios normativos morais que formariam regras de conduta e parâmetros de caráter para se relacionar com o mundo natural, que de início poderiam se basear nos princípios ambientais surgidos na Convenção de Estocolmo de 1972 e a Convenção do Rio de Janeiro de 1992. Não é uma questão de amor, mas de respeito pela natureza de forma que se criem responsabilidades centradas na vida de todos no planeta, para que se mantenha a vida em todas as suas formas.

O SARS-CoV2 surge da alteração ambiental impensada que segundo vários autores, (PLOWRIGHT et al., 2017, LIU et al., 2020; XIAO et al., 2020 apud ACOSTA et al., 2020, p. 192) e se tem fortes evidências de que o consumo de animais silvestres tenha dado início à COVID-19. Porque, 
como afirmam Acosta et al. (2020), é uma doença oriunda de animais. E outras doenças já surgiram deste contato, inclusive doenças raras em animais como o ebola, por exemplo, assim, quanto maior a proximidade entre animais silvestres e seres humanos mais facilmente os agentes infecciosos circulam.

As modificações climáticas também podem conduzir a um quadro de novas epidemias, pois o degelo de determinadas áreas pode reavivar vírus que atacaram seres humanos no passado ou mesmo mudar as relações cíclicas da vida que podem trazer novas doenças epidêmicas.

As mudanças climáticas alteram a expressão dos padrões atmosféricos das estações, podendo deslocar e até aumentar períodos com condições climaticamente favoráveis as infecções. O clima e fator primário aos nichos ecológicos, determinando as áreas das distribuições das espécies. Alterações climáticas degradam a adequabilidade dos habitats, que em certas situações obrigam as espécies a se dispersarem para novas localidades. O vírus, pela sua condição de parasita obrigatório, se dispersa junto com as espécies, levando e elevando o risco de spillover para novas áreas e para outras espécies (ACOSTA et al., 2020, p.206).

A Pandemia deveria ser vista como um momento de reflexão sobre o estado do planeta. Nesse momento de paralisação geral do mundo, para proposições mais adequadas de relacionamento entre seres vivos e o meio natural.

É hora de repensar os deveres para com os seres vivos em geral, nas palavras de Taylor (1981, p. 6):

We can say that the actions one performs and the character traits one develops in fulfilling these moral requirements are the way one expresses or embodies the attitude in one's conduct and character. In his famous essay, "Justice as Fairness, " John Rawls describes the rules of the duties of human morality (such as fidelity, gratitude, honesty, and justice) as "forms of conduct in which recognition of others as persons is manifested." I hold that the rules of duty governing our treatment of the natural world and its inhabitants are forms of conduct in which the attitude of respect for nature is manifested. ${ }^{10}$

Esta redução de emissões de GEE e de poluição mostraram a possibilidade de mudar, a questão é se a humanidade quer mudar ou se manter no caminho inconsequente que estava nas relações indivíduo indivíduo e indivíduo - mundo natural. Somente o querer pode gerar a

10 Podemos dizer que as ações que se realizam e os traços de caráter que se desenvolvem no cumprimento destes requisitos morais são a forma como se expressa ou encarna a atitude na sua conduta e caráter. No seu famoso ensaio, "Justiça como Equidade", John Rawls descreve as regras dos deveres da moral humana (tais como fidelidade, gratidão, honestidade e justiça) como "formas de conduta em que se manifesta o reconhecimento dos outros como pessoas (em tradução livre). 
mudança de padrões éticos para se pensar o meio ambiente, antes que a situação se torne descontrolada e possa conduzir ao fim da vida humana como é conhecida atualmente.

\section{CONSIDERAÇÕES FINAIS}

Um dos maiores problemas ambientais da atualidade é o aquecimento global decorrente da potencialização do efeito estufa natural pela emissão de GEE por diversas atividades antrópicas, principalmente a queima de combustíveis fósseis, ainda a principal fonte na matriz energética mundial.

Os esforços que vêm sendo feitos pelos estados membros desde a Rio 92 com a criação da Convenção do Clima e as reuniões anuais dos estados membros (COP) ainda não surtiram os efeitos desejados para controlar o aumento da temperatura média da Terra. O Protocolo de Kyoto (1997) fracassou e o Acordo de Paris (2015) vem encontrando dificuldades, com o não comprometimento dos grandes poluidores como os Estados Unidos, um dos maiores emissores de GEE.

O que ninguém imaginava é que um vírus surgido na China, no final de 2019, o SARS-CoV-2, mais conhecido como o novo coronavírus, patógeno da pandemia da COVID-19, seria capaz de paralisar o mundo, reduzindo muitas atividades humanas, principalmente a queima de combustíveis fósseis e consequentemente as emissões de GEE e demonstrar que podemos reduzir as emissões a um custo que pode ser mitigado se forem feitos de forma programada em médio e longo prazo, apesar de no Brasil não ter havido mudança, já que as emissões estão ligadas em especial ao desmatamento ilegal na Amazônia. Segundo os dados do sistema de alerta DETER, os focos de desmatamento vêm crescendo, mesmo no período da pandemia da COVID-19, demonstrando que é necessário repensar a relação do Brasil com a Amazônia.

No tocante à qualidade do ar nos níveis local e regional, observam-se melhorias em todas as cidades pesquisadas no país e no mundo, com redução da concentração dos principais poluentes, certamente pela política de isolamento recomendada pela OMS e adotada pela maioria dos governos nacionais. Além da redução da queima de combustíveis fósseis, a redução na mobilidade de pessoas, bens e serviços reduziu muitas atividades da indústria, comércio e serviços, que também pode impactar nas modificações climáticas a médio prazo.

Se por um lado o isolamento provocado pela pandemia obteve êxitos 
no meio atmosférico em termos de redução de emissão de GEE e de outros poluentes, bem como de trazer a reflexão a atual relação ser humano - mundo natural, por outro, causa preocupação pela capacidade do novo Coronavírus permanecer em gotículas suspensas no ar e contribuir para a contaminação da população e gerar impactos econômicos e sociais de grandes proporções no espaço de tempo que está ocorrendo. O futuro não é claro, mas é possível perceber que é necessária uma rediscussão sobre a relação ser humano - mundo natural com uma transição para novos princípios morais, baseados em uma consciência ambiental, que podem evitar futuras epidemias e reduzir os efeitos climáticos e fundados nos princípios ambientais propalados principalmente pelas principais convenções sobre meio ambiente ou os novos comportamentos propostos internacionalmente como os objetivos de desenvolvimento sustentáveis (ODS).

\section{REFERÊNCIAS}

ACOSTA, A. L. et al. Interfaces à transmissão e spillover do coronavírus entre florestas e cidades. Estudos Avançados, São Paulo, v. 34, n. 99, p. 191-208, ago. 2020. Disponível em: http://www.scielo.br/scielo.php?script=sci_arttext\&pid=S0103-40142020000200191\&lng=en\&nrm=iso. Acesso em: 10 out. 2020.

BRANCO, S. Elementos de ciências do ambiente. São Paulo: CETESB, 1982.

BRASIL. Lei n. 13.979, de 6 de fevereiro de 2020. Dispõe sobre as medidas para enfrentamento da emergência de saúde pública de importância internacional decorrente do coronavírus responsável pelo surto de 2019. Diário oficial da União de 7 fevereiro de 2020. Disponível em: http:// www.planalto.gov.br/ccivil_03/_ato2019-2022/2020/lei/113979.htm. Acesso em: 5 maio 2020.

CABIDELLI, E. FEAM participa de Conferência Internacional da Poluição do Ar. FEAM - Fundação Estadual do Meio Ambiente (Minas Gerais), 29 jul. 2019. Disponível em: http://www.feam.br/banco-de-noticias/1802-feam-participa-de-conferencia-internacional-da-poluicao-do-ar. Acesso em: 2 jul. 2020.

CETESB - COMPANHIA AMBIENTAL DO ESTADO DE SÃO PAULO. Boletim da Qualidade do ar. São Paulo: CETESB, 2020. Disponível em: https://servicos.cetesb.sp.gov.br/qa/. Acesso em: 30 jul. 2020. 
CHAKRABORTY, L.; PRASENJIT, M. COVID-19 outbreak: migration, effects on society, global environment, and prevention. Rev. Science of The Total Environment, Geneva, v. 728, ago. 2020. Disponível em: https://search.bvsalud.org/global-literature-on-novel-coronavirus-2019-ncov/resource/en/covidwho-102210. Acesso em: 30 ago. 2020.

CIRNE, M. B. Enfoque dogmático para o Estado de Direito Ambiental. Veredas do Direito, Belo Horizonte, v. 16, n. 35, p. 219-244, maio/ago. 2019. Disponível em: http://revista.domhelder.edu.br/index.php/veredas/article/ view/1584. Acesso em: 30 ago. 2020.

CONAMA - CONSELHO NACIONAL DO MEIO AMBIENTE. Resolução $n$. 436, de 22 de dezembro de 2011. Estabelece os limites máximos de emissão de poluentes atmosféricos para fontes fixas instaladas ou com pedido de licença de instalação anteriores a 02 de janeiro de 2007. 2011. Disponível em: http://www2.mma.gov.br/port/conama/legiabre.cfm?codlegi $=660$. Acesso em: 2 jul. 2020.

CONAMA - CONSELHO NACIONAL DO MEIO AMBIENTE. Resolução n. 491, de 19 de novembro de 2018. Dispõe sobre padrões de qualidade do ar. 2018. Disponível em: https://www.in.gov.br/web/guest/materia/-/asset_publisher/Kujrw0TZC2Mb/content/id/51058895/do1-2018-11-21-resolucao-n-491-de-19-de-novembro-de-2018-51058603. Acesso em: 3 jul. 2020 .

DIAS, A. A. C.; ANDRADE-NETO, A. V.; MILTÃO, M. S. R. A atmosfera terrestre: composição e estrutura. Caderno de Física da UEFS, Feira de Santana, v. 5, n. 1-2, p. 21-40, 2007. Disponível em: http://dfisweb.uefs.br/ caderno/vol5n12/Atmosfera.pdf. Acesso em: 3 jul. 2020.

FEAM/MG - FUNDAÇÃO ESTADUAL DO MEIO AMBIENTE DE MINAS GERAIS. Emissão de fontes móveis. 2020. Disponível em: http:// www.feam.br/qualidade-do-ar/emissao-de-fontes-moveis. Acesso em: 2 jul. 2020.

FEAM/MG - FUNDAÇÃO ESTADUAL DO MEIO AMBIENTE DE MINAS GERAIS. Emissão de fontes fixas. 2015. Disponível em: http://www. feam.br/qualidade-do-ar/emissao-de-fontes-fixas. Acesso em: 2 jul. 2020.

INEA/RJ - INSTITUTO ESTADUAL DO MEIO AMBIENTE DO RIO DE JANEIRO. Secretaria do Ambiente e Sustentabilidade e INEA promovem a Semana do Ambiente 2020. Rio de Janeiro: INEA, 2020. Disponível 
em: http:/www.inea.rj.gov.br/secretaria-do-ambiente-e-sustentabilidade-e-inea-promovem-a-semana-do-ambiente-2020/. Acesso em: 3 jul. 2020.

INPE - INSTITUTO NACIONAL DE PESQUISAS ESPACIAIS. Mapa de Desmatamento - PRODES e Mapa de Avisos - DETER. TerraBrasilis, 2020. Disponível em: http://terrabrasilis.dpi.inpe.br/app/dashboard/alerts/ biomes/cerrado/daily/. Acesso em: 22 jul. 2020.

IPCC - INTERGOVERNMENTAL PANEL CLIMATE CHANGE. Climate change 2014: synthesis report. Genève: IPCC, 2014. Disponível em: https://archive.ipcc.ch/pdf/assessment-report/ar5/syr/SYR_AR5_FINAL_ full_wcover.pdf. Acesso em: 17 jul. 2020.

IRENO, P. K. M. Avaliação da rede de automonitoramento manual e classificação da qualidade do ar dos municípios do vetor norte da RMBH. (Relatório final da Bolsa de Iniciação Científica). Belo Horizonte: FEAM, 2015. Disponível em: http://www.feam.br/images/stories/2015/QUALIDADE_AR/RELAT\%C3\%93RIO_Ar_Vetor_Norte_RMBH_Editado_02.12.pdf. Acesso em: 3 jul. 2020.

LIMA, Y. O. R.; COSTA, E. A. Regulamento Sanitário Internacional: emergências em saúde pública, medidas restritivas de liberdade e liberdades individuais. Revista Visa em Debate - Sociedade, Ciência e Tecnologia, Rio de Janeiro, v. 3, n. 1, p. 10-18, 2015. Disponível em: http://www6. ensp.fiocruz.br/visa/files/266-2299-2-PB_0.pdf. Acesso em: 3 jul. 2020.

MENDONÇA, F. Aquecimento global e saúde: uma perspectiva geográfica - notas introdutórias. Terra Livre, São Paulo, ano 19, v. I, n. 20. p. 205-221, jan./jul. 2003. Disponível em: https://www.agb.org.br/publicacoes/index. php/terralivre/article/view/184/168. Acesso em: 3 jul. 2020.

MMA - MINISTÉRIO DO MEIO AMBIENTE DO BRASIL. Padrões de qualidade do ar. Brasília, DF: MMA, 2020a. Disponível em: https://www. mma.gov.br/cidades-sustentaveis/qualidade-do-ar/padroes-de-qualidade-do-ar.html\#: :text=Segundo\%20esta\%20 Resolu \%C3\%A7\% C3\%A3 o\% $2 \mathrm{C} \% 20 \mathrm{o} \%$ 20padr\% $\% 3 \% \mathrm{~A} 3 \mathrm{o}$, preservados $\% 20 \mathrm{em} \% 20 \mathrm{rela} \% \mathrm{C} 3 \% \mathrm{~A} 7 \%$ C3\%A3o\% 20aos\%20riscos. Acesso em: 3 jul. 2020.

MMA - MINISTÉRIO DO MEIO AMBIENTE DO BRASIL. Conferência das Partes-COP. Brasília, DF: MMA, 2020b. Disponível em: https:// mma.gov.br/biodiversidade/conven $\% \mathrm{C} 3 \% \mathrm{~A} 7 \% \mathrm{C} 3 \% \mathrm{~A} 3 \mathrm{o}$-da-diversidade-biol\%C3\%B3gica/conferencia-das-partes.html. Acesso em: 27 jul. 2020. 
MMA - MINISTÉRIO DO MEIO AMBIENTE DO BRASIL. Poluentes atmosféricos. Brasília, DF: MMA, 2013. Disponível em: https://www. mma.gov.br/cidades-sustentaveis/qualidade-do-ar/poluentes-atmosf\%C3\%A9ricos.html. Acesso em: 2 de jul. 2020.

MMA - MINISTÉRIO DO MEIO AMBIENTE DO BRASIL. Efeito estufa e aquecimento global. Brasília, DF: MMA, 2012. Disponível em: https:/www.mma.gov.br/informma/ item/195-efeito-estufa-e-aquecimento-global\#: :text $=\mathrm{O} \% 20$ efeito $\% 20$ estufa $\% 20 \%$ C3\%A9\%20um, Terra $\% 2 \mathrm{C} \% 20$ promovendo $\% 20$ o $\% 20$ seu $\% 20$ aquecimento. Acesso em: 30 jun. 2020.

MYLLYVIRTA, L. Analysis: China's CO2 emissions surged past pre-coronavirus levels in may. CarbonBrief, 29 jun. 2020. Disponível em: https:// www.carbonbrief.org/analysis-chinas-co2-emissions-surged-past-pre-coronavirus-levels-in-may?utm_content=bufferd $871 \mathrm{f} \& u t m \_$medium $=$social\&utm_source=twitter.com\&utm_campaign=buffer. Acesso em: 28 de jul. 2020.

OLIVEIRA, C. A. Ficar em casa salva vidas? Uma estimativa dos impactos do isolamento social nos casos e nos óbitos por COVID-19 registrados no Brasil. Rio Grande: Universidade Federal do Rio Grande, 2020. Disponível em: https://www.researchgate.net/profile/Cristiano_Oliveira10/publication/341170789_Does_staying_at_home_save_lives_An_estimation_of_the_impacts_of_social_isolation_in_the_registered_cases and_deaths_by_Covid-19_in_Brazil/links/5eb213b0a6fdcc7050ad5dc6/ Does-staying-at-home-save-lives-An-estimation-of-the-impacts-of-social-isolation-in-the-registered-cases-and-deaths-by-Covid-19-in-Brazil.pdf. Acesso em: 24 jun. 2020.

OLIVEIRA, M. N.; CAMPOS, M. A. S.; SIQUEIRA, T. D. A. Coronavírus: globalização e seus reflexos no meio ambiente. Boletim Informativo Unimotrisaúde em Sociogerontologia, Manaus, v. 20 n. 14, 2020. Disponível em: https://www.periodicos.ufam.edu.br/index.php/BIUS/article/ view/7859/5551. Acesso em: 30 jul. 2020.

OMS - ORGANIZAÇÃO MUNDIAL DA SAÚDE. Calidad del aire y salud. Genève: OMS, 2018. Disponível em: https://www.who.int/es/news-room/fact-sheets/detail/ambient-(outdoor)-air-quality-and-health. Acesso em: 24 de jul. 2020. 
OMS - ORGANIZAÇÃO MUNDIAL DA SAÚDE. Criterios de salud pública para ajustar las medidas de salud pública y sociales en el contexto de la COVID-19: anexo del documento Consideraciones relativas a los ajustes de las medidas de salud pública y sociales en el contexto de la COVID-19. Genève: OMS, 2020. Disponível em: https://apps.who.int/iris/ handle/10665/332169. Acesso em: 3 jul. 2020.

OMS - ORGANIZAÇÃO MUNDIAL DA SAÚDE. Reglamento Sanitario Internacional de 2005. 3. ed. Genève: OMS, 2016. Disponível em: https:// apps.who.int/iris/bitstream/handle/10665/246186/9789243580494-spa. pdf;jsessionid=718EB342000E8A46542D42BEB2CE1E89? sequence=1. Acesso em: 25 ago. 2020

PARANAIBA, G. Poluição do ar reduziu até $45 \%$ em BH durante a pandemia. Belo Horizonte: FEAM, 2020. Disponível em: http:/www.feam.br/ banco-de-noticias/1928-analise-da-feam-mostra-que-poluicao-do-ar-reduziu-ate-45-em-bh-durante-a-pandemia. Acesso em: 3 jul. 2020.

PERES, L. V. Análise da ocorrência dos eventos de efeitos secundários do buraco de ozônio antártico sobre o Sul do Brasil. Santa Maria: Universidade Federal de Santa Maria, 2008. Disponível em: http://mtc-m16c.sid. inpe.br/col/sid.inpe.br/mtcm18@80/2008/12.08.21.12/doc/Microsoft $\% 20$ Word\%20-\%20Relat\%F3rio\%20Final\%20PIBIC2008\%20-\%20Nadiara\%20Pereira.pdf. Acesso em: 24 jun. 2020.

POLUIÇÃO diminui 50\% em países da Europa com 'lockdowns' por coronavírus. UOL Notícias, 16 abr. 2020. Disponível em: https://noticias.uol. com.br/meio-ambiente/ultimas-noticias/redacao/2020/04/16/poluicao-diminui-50-em-alguns-paises-da-europa.htm. Acesso em: 27 jul. 2020.

REI, F. C. F.; GONÇALVES, A. F.; SOUZA, L. P. Acordo de Paris: reflexões e desafios para o regime internacional de mudanças climáticas. Veredas do Direito, Belo Horizonte, v. 14, n. 29, p. 81-99, maio/ago. 2017. Disponível em: http://revista.domhelder.edu.br/index.php/veredas/article/ view/996/0. Acesso em: 2 jul. 2020.

RIO DE JANEIRO (Cidade). Secretaria Municipal de Meio Ambiente. Boletim da Qualidade do Ar. 30 jul. 2020. Disponível em: http://jeap.rio. rj.gov.br/je-metinfosmac/boletim. Acesso em: 30 jul. 2020.

SÃO PAULO (Estado). COVID-19: Cetesb constata diminuição da poluição em SP durante a quarentena. Portal do Governo, 1 abr. 2020. Disponível 
em: https://www.saopaulo.sp.gov.br/ultimas-noticias/covid-19-cetesbconstata-diminuicao-da-poluicao-em-sp-durante-a-quarentena/. Acesso em: 3 jul. 2020.

SCHUCHMANN, A. Z. et al. Isolamento social vertical X Isolamento social horizontal: os dilemas sanitários e sociais no enfrentamento da pandemia de COVID-19. Braz. J. Hea. Rev., Curitiba, v. 3, n. 2, p. 3556-3576, mar./abr. 2020. Disponível em: https://doi.org/10.34119/bjhrv3n2-185. Acesso em: 30 ago. 2020.

SILVA, C. M. et al. A pandemia de COVID-19: vivendo no antropoceno. Revista Virtual de Química, Rio de Janeiro, v. 12, n. 4, p. 1-16, jul. 2020. Disponível em: http://static.sites.sbq.org.br/rvq.sbq.org.br/pdf/RVq070720-a8.pdf. Acesso em: 23 jul. 2020.

TAMANINI, M. Os impactos da pandemia do Coronavírus na qualidade do ar. Tecmundo, 26 abr. 2020. Disponível em: https://www.tecmundo.com.br/ciencia/152463-coronavirus-impactos-pandemia-qualidade-ar. htm. Acesso em: 17 jul. 2020.

TAYLOR, P. W. The ethics of respect for natur, 1981 Disponível em: https://rintintin.colorado.edu/ vancecd/phil308/Taylor.pdf. Acesso em: 23 jul. 2020.

UCHÔA, S. B. B.; UCHÔA, B. B. Coronavírus (COVID-19): um exame constitucional e ético das medidas previstas na Lei n. 13.979, de 6 de fevereiro de 2020. Cadernos de Prospecção, Salvador, v. 13, n. 2, ed. esp., p. 441-458, abr. 2020. Disponível em: https://portalseer.ufba.br/index.php/ nit/article/view/36163/20967. Acesso em: 23 jul. 2020.

UFJF - UNIVERSIDADE FEDERAL DE JUIZ DE FORA. Pandemia e meio ambiente: impactos momentâneos ou nova normalidade? UFJF Noticias, 24 abr. 2020. Disponível em: https://www2.ufjf.br/noti$\operatorname{cias} / 2020 / 04 / 24 /$ pandemia-e-meio-ambiente-impactos-momentaneos-ou-nova-normalidade/. Acesso em: 9 nov. 2020.

VALLERO, D. Fundamentals of air pollution. 4. ed. Amsterdam: Elsevier, 2008. 
Artigo recebido em: 18/09/2020. Artigo aceito em: 24/11/2020.

\section{Como citar este artigo (ABNT):}

RIBEIRO, J. C. J.; CUSTÓDIO, M. M.; PRAÇA, D. H. P. COVID-19: reflexões sobre seus impactos na qualidade do ar e nas modificações climáticas. Veredas do Direito, Belo Horizonte, v. 17, n. 39, p. 265-296, maio/ago. 2020. Disponível em: http://www.domhelder.edu.br/revista/index.php/veredas/article/view/1960. Acesso em: dia mês. ano. 